\title{
An Exploratory Study of the Language-learning Style Preferences of Iranian EFL High School Students
}

\author{
Afsaneh Effatdokht Ramezani (Corresponding author) \\ School of Language Studies and Linguistics, Faculty of Social Sciences and Humanities, Universiti Kebangsaan Malaysia, Malaysia \\ E-mail: ramezani.afsaneh@hotmail.com \\ Meysam Dehgahi \\ Independent Researcher \\ Hanie Hashemi \\ Independent Researcher
}

Doi:10.7575/aiac.alls.v.6n.2p.150

URL: http://dx.doi.org/10.7575/aiac.alls.v.6n.2p. 150
Received: 08/12/2014

Accepted: 06/02/2015

\begin{abstract}
This study explored the learning style preferences of 40 Iranian students at Marefat Iranian high school in Kuala Lumpur of which, 20 are females and 20 are males. To this end, this study used structured interview to elicit in-depth information from the students. The results of the study showed that learning style preferences of Iranian students were different according to their gender. Female students preferred auditory learning as their major learning style, while male students preferred kinesthetic more. Moreover, the findings revealed that Kinesthetic learning was the least preferred learning style of the most female students, whereas the least preferred learning style of male students was tactile learning.
\end{abstract}

Keywords: Learning Style Preferences, High School Students, Gender, EFL

\section{Introduction}

Learning process can be obtained, held and attained through different styles. Understanding these styles is important in a learning process. Every learning style raises the success rate of each student especially when it matches with individual need. Different researchers gave different definitions of learning style (LS). Reid (1995) defines learning style as an individual's habitual, natural and desired way of receiving, processing, and keeping new data. According to Oxford (2003), learning style is the general approaches like visual or auditory that people use in learning a new language or any other subjects.

Learning style is generally conceived as faiths, preferences and manners used by individuals to help their learning under the classroom or environmental conditions (Borich and Tombari 1997; Hohn 1995).According to Brown (2000) "learning styles serve as relatively stable indicators of how learners perceive, interact with, and respond to the learning environment" (p. 114).

According to Dunn and Dunn (1992), learning style is defined as the way that forces learners to concentrate, absorb and retain new and difficult information. Lay Cock $(1978$, p. 45) explains learning style as "an individual characteristic way of responding to certain variables in the instructional environment". Kalsbeek (1989) believed that "learning style can be understood as a person's preferred approach to information processing, idea formation and decision making" (p. 2) .

The vital concept for each student to succeed in his/her study is learning style. Many previous studies have been confirmed that an influential learning is obtained through various learning styles and learners who have the ability to use those different learning styles, their learning outcome is high (Keefe, 1982; Felder, 1995; Reid, 1987, Reid, 1998; Claxton and Murell, 1985; Riazi and Riasati, 2007; Mulalic, Mohd Shah and Ahmad, 2009; Bidabad and Yamat, 2010; Vaseghi, Ramezani and Gholami, 2012; Vaseghi, Barjesteh, and Shakib, 2013). If the students know their learning styles and grasp their own learning preferences, then they would be able to perform well in class learning styles and preferences vary for each of us and in different situations. For instance, some students like to learn by verbal explanation, whereas the others like to learn by reading textbooks (Riazi and Riasati 2007). Moreover, learners learn and grasp effectively in various ways. They learn either orally or in writing or learn visually through graphs and figures. Generally, Learning styles as Keffe (1982) pointed out refer to the cognitive, emotional, and psychological behaviors which are related to learners' understanding, feeling and interacting with their learning environment. In a similar vein, Oxford (2003) aptly stated that using various learning styles as general approaches would not only help acquire a new language but also help learn any other subjects.

According to Keefe $(1979$, p. 4), learning styles is an "affective, cognitive, and physiological traits that are relatively stable indicators of how learner perceive, interact with, and respond to the learning environment". It means that students 
would respond to what they learn on the basis of communication which helps them to understand and use the knowledge based on their physical and mental capability to receive the knowledge. This means that each learner has his/her own learning style preferences. Dunn and Griggs (1998) defined learning style as the attitude, favorites, and conducts that learners utilize in their learning. Moreover, according to them, the learning methods might have a lot or a bit of differences.

English in Iran used and taught as a foreign language that is significant for educational, scientific, and socio-cultural reasons (Rashidi, 1995). Teaching English in Iranian public schools starts from the first grade of middle school until the end of secondary school and students have the opportunity to study the language around three hours class per week.

\subsection{Statement of the Problem}

Iranian English learners have difficulties in learning English as a foreign language because they learn English in a country in which the native language is Persian. According to Bidabadi and Yamat (2010, p. 220), in Iran, "learners' learning styles have been ignored and have been seen as an insignificant component in the learning process among Iranian EFL learners". Furthermore, Riazi and Riasati (2007) stated that Iranian learners have two reasons to be passive English learners. The findings of their study showed that the students felt that their English language skills are improving by doing the communicative approach in group work. The study found that learners preferred a communicative approach. Nevertheless, Iranian EFL learners particularly those who are freshmen, are still observed to be passive learners of English. They might be not aware of their learning styles and perhaps there is a mismatch between learners' learning styles and teaching styles at higher institutions. Another problem discovered in this area is there are few studies conducted on Iranian learners' learning styles particularly in high school levels.

\subsection{Research Objectives}

The purpose of this study is to explore the most and least preferred learning styles of male and female students at Marefat Iranian EFL high school. Moreover, this study determines the reasons for utilizing the most preferred and least preferred learning styles of male and female students at Marefat Iranian EFL high school.

\subsection{Research Questions}

This study aims at seeking the answers to the following research questions:

1. What is the most and the least preferred learning style of male and female students at Marefat Iranian EFL high school?

2. What are the reasons for utilizing the most preferred and least preferred learning styles of male and female students at Marefat Iranian EFL high school?

\section{Literature Review}

Skinner (1974) state that learning is any change in behavior. Learning is "the process whereby knowledge is created through the transformation of experience" (Kolb 1984, p. 41). According to Sims and Sims (1995) "learning happens when one adopts newly or modifies existing behavior patterns in a way that has some influence on future performance or attitude". Thus, learning is a " relatively permanent change in performance by an individual" (Harasyrn, Leong, Lucier, \& Lorsheider 1995, p. 56).

The ways that an individual usually attains, holds, and recovers information are defined as the individual's learning style. According to Felder \& Henriques (1995), learning styles and its effect on student performance have been extensively researched time and time again in the educational research literature, specifically in the context of differences in student learning styles by Felder and Brent (2005). Furthermore, they argued that many learning style assessment instruments have been developed in the past five decades. In recent years, there has been a shift from an instructional paradigm to a learner-oriented approach towards language learning/teaching thus, understanding the way people learn is of crucial importance and is the key to educational improvement.

According to Reid (1987), learning styles or learning preferences are the different ways of how a learner acquires, retains and retrieves information. There are growing evidences in literature demonstrating that learning styles are one of the components of language learning procedures (e.g., Cohen 2003; Ehrman, Leaver \& Oxford 2003; Oxford 1999; Oxford, Ehrman \& Lavine 1991). Kang (1999, p. 1) states that "learning styles are internally based characteristics of individuals for the intake or understanding of new information". In addition, Dörnyei (2005) reports that the meaning of learning style (LS) is an individual approach to learning, a customary way the individual perceives, and interacts with the learning environment and responds to it.

Some personality characteristics have been associated with successful language learning and these include "having high self-confidence (Long 1991, p. 184 in Larson Freeman), being curious (Ellis \& Sinclair, 1985 in Willis 2001, p. 158), and being willing to take risks" (Ruben 1979 in Willis 2001, p. 156).Among these characteristics, motivation and attitude have also been recognized as important variables, which influence foreign language learning.

\subsection{Related Empirical Studies on Learning Styles}

As an interesting area for learning research, learning styles have attracted a huge number of researchers who have examined them from different angles. Researchers' attempts to provide better understanding of effective language learning and learners have identified various learning styles reported by students or observed by researchers in different learning contexts. Therefore, this section provides a detailed review of some previous studies which have been conducted on learning styles in general including ESL and EFL learners' learning styles in different contexts. 
A study by Reid (1987) examining 90 students' preferred types of learning styles who were joining a Chinese university in the USA revealed that the participants preferred kinesthetic and tactile learning styles while they did not prefer group learning style. Following Reid's study, Melton (1990) carried out a study involving 331 students joining five schools in The People's Republic of China (PRC). Findings showed that multiple learning styles including kinesthetic, tactile, and individual learning styles were the students' preferred learning styles. In a survey distributed to 147 adult L2 immigrants in the US, Rossi-Le (1995) obtained results which were consistent with Reid's (1987) findings in the sense that the participants showed preference of kinesthetic and tactile learning styles as their major learning styles. Another study by Sharifah Azizah and Wan Zalina (1995) among the Malay students in a Malaysian tertiary institution displayed similar findings to the previous findings since individual learning style and kinesthetic and tactile learning styles were preferred by the students, and added to these, other styles such as visual and auditory styles were the participants' preferences and group learning styles were found their least preferred learning styles.

Moreover, Similar findings indicating that kinesthetic, tactile, and group styles were perceived as the major learning style preferences for ESL learners were obtained by Rosniah Mustaffa (2007) (as cited in Ahmad, 2011) in her study carried out among Bachelor of Arts students in English language studies at Universiti Kebangsaan Malaysia during eight months (two semesters). The study also revealed additional results concerning the participants' visual, auditory, and incongruent styles as their minor learning styles. Other consistent results were those discussed by Riazi and Mansoorian (2008) who surveyed the preferred learning styles of $(\mathrm{N}=300)$ Iranian EFL students who were studying English at EFL institutes in different cities in Iran as it was found that the auditory, visual, tactile, and kinesthetic learning styles were preferred by students as the major styles and they chose the individual and group learning styles as their minor styles.

In contrast to the previously reviewed findings of previous studies on ESL and EFL learning style preferences, a few studies investigating the same research area in different contexts showed that some of the same previously reported preferred learning styles as previously discussed were selected as learners' negative learning styles in such studies. One of these studies is the one by Adi Afzal Ahmad (2011) which aimed at identifying the learning style preferences of 252 low level students at a local tertiary institution. His findings showed that the students did not have any major or even minor learning style preference. All six learning styles were negative learning style preferences and among six learning styles, individual learning was the least preferred learning style.

All previous studies previously presented almost focus on learning styles by exploring, identifying and examining them among learners who were not categorized into groups, but as learners who usually constituted one group in each study coming from. However, another body of previous research on learning styles has concentrated on this interesting area where each study tended to categorize the participating learners into two or more than two groups (based on their levels, majors or fields of study, etc) for the purpose of finding out the similarities and differences between such groups of learners in terms of their preferred learning styles. In a study by Tai (1999a), 209 traditional and nontraditional EFL students in junior colleges from five randomly selected schools in Taiwan were selected for comparing their learning styles according to Reid. The results showed that the most preferred learning style was auditory and group learning styles, while visual and individual learning styles were as their least preferred learning styles. Traditional students showed that they strongly agreed with visual and individual learning styles than nontraditional students.

\subsection{Gender in Learning Style}

Gender differences might be seen in student learning (Arbaugh, 2000). "Learning as a complicated skill is not just a matter of acquiring information, but also entails remembering and recollection and the application of acquired information to master and develop new skills" (Garland et al. 1998, p. 1). According to Lewis and Orton (2000, p. 47), a learning style is a "pattern of behavior that learners use for learning. Different learners have different learning styles". Learner variables had influence on language learning styles. Among them gender was the most influential one that had a significant influence on participants' language learning styles (Chang and Shen, 2005).

\subsubsection{Studies on the Relationship between Gender and Learning Styles}

Gender as an important factor in learning styles was a variable that has been evaluated by nearly all of the previous studies.

Almost most of these studies examining learning styles between males and females have revealed the existence of significant differences in learning styles employed or utilized by the two different groups in different learning contexts. Dorsey and Pierson (1984) used Kolb's Learning Style Inventory and found a major difference between male and female students learning style preferences. They studied 513 nontraditional students in Southwest Texas State University in the fall of 1982 and understood that the dominant learning ability for males was abstract conceptualization (AC) and for females was active experimentation (AE). Pettigrew and Zakrajesk (1984) indicated that male students preferred hands-on learning tasks, whereas female students preferred a well-organized presentation of course material.

In examining the gender impact on learning styles among 209 traditional and nontraditional EFL students in junior colleges from five randomly selected schools in Taiwan, Tai (1999a) found out that male and female traditional EFL junior college students differ in their preferred learning styles; besides the auditory style, female students preferred the kinesthetic style, while male students preferred group learning style. Generally, female nontraditional EFL junior college students preferred all learning styles more than male students. Dunn et al. (2001) declared that learning styles of students will be different according to their gender. Summarizing their findings, Honigsfeld and Dunn (2006, p. 3) stated, "globally speaking, in almost every study, the following results were revealed: Adult males and females had 
significantly different learning styles from each other. For example, female students in every nation were more auditory, motivated, persistent and responsible (conforming) than their male counterparts".

The second largest group of such studies examining learning styles between males and females have revealed that the differences in learning styles employed or utilized by males and females in different learning contexts were not significant, but they were little or minor differences. According to Reid (1987), male students preferred tactile and visual learning styles more than females. Isemonger and Sheppard (2003) following Reid (1987) and they have used a translate version of PLSPQ for 710 Korean students at the Pusan University of Foreign Studies. Following Reid's study, Melton in 1990 investigated 331 students' learning style preferences at five schools in The People's Republic of China (PRC).one of the learning style variables was the students' gender in this research. The results revealed that female students were much more auditory than male students. Also, male students preferred tactile (related to "hands on" activities, touching, drawing) and kinesthetic (doing activities, role playing) learning styles more than female students.

The aforementioned studies indicated that gender, as a factor in learning styles is still a variable that should be included in the explanation of learning styles.

\section{Methodology}

\subsection{Participants}

The data for the present study were gathered from Marefat Iranian EFL high school students in Kuala Lumpur. The total number of respondents who participated in this study is 40 (20 female and 20 male). The learners were between 15-17 years old in different 3 levels of high school. Students in $1^{\text {st }}$ level of high school in Iranian Educational system were 15 years old who studied English as a foreign language in fourth year of education. Students in $2^{\text {nd }}$ level of high school were 16 years old who studied English as a foreign language in fifth year of education. In the $3^{\text {rd }}$ level of high school students were 17 years old who studied English as a foreign language in sixth year of education.

\subsection{Instruments}

This study used interview to collect data. In this study, the structured interview was used to elicit in-depth information from the students. The interview questions were adapted from Wong (2010). These questions mainly asked about the most and least preferred learning styles. According to McDonough and McDonough (1997), while a semi- structured interview allowed for a greater flexibility, a structured interview is formalized and limited to set questions. In structured interview, the interviewer has a standard set of questions that are asked of all candidates. This structured interview questions were based on six Learning Styles. This will help the researcher to get information on learning style preferences of male and female students and the reasons for using these learning styles. The interview portion of the study involved asking forty participants (20 males and 20 females) a series of five questions (Appendix A). Structured interview was used because the researcher could get the answers of research question through these fixed questions (5 questions). The interviews were conducted in both languages; English and Persian language depending on the preferred language used by the learner. This was to ascertain that the questions asked from the researchers are understood by the learner.

\subsection{Procedures}

The researchers gave lucid instructions about the purpose of the study to the students. This was to ensure that the students were clear and familiar with the purpose of the learning style preference.

The interview was conducted to the forty students where the interview questions were asked from each student. They were inquired to answer the questions according to their experience in EFL learning. The researchers gave ample time to the students to answer the questions to elicit accurate answers from the students as getting specific answers from them. All the interview sessions were recorded because the researchers did not intend to miss any single word from the learners and to get as accurate responses as possible from them.

\subsection{Data Analysis}

The interviews were audio taped to record the learners' responses and were transcribed in verbatim. This was done immediately to avoid missing any important points. Most importantly, the interview transcriptions were coded into two groups (Group 1: Female and Group 2: Male), number of question (question 1 till 5) and number of learner per group (learner 1 till learner 20). In analyzing the data, the transcription was scrutinized to make sense of the data.

\section{Findings and Discussions}

\subsection{Learning Style Preferences of Female and Male Students}

The overall results of data collected from the interview of the Iranian high school students' responses are adequately long due to their limited language proficiency. They could not articulate their ideas well due to having insufficient vocabulary.

The results of the interview showed that most of the female students preferred auditory learning style. Female students with traditional belief prefer auditory learning style more than male students as there are some previous researches (Feingold 1992; Li 2006) which stated that female students had better listening ability and higher verbal capability. The result of this study concurs with the study conducted by (Feingold 1992; Li 2006) and showed that most of the female participants selected auditory learning as their major learning style. This implicates that the learning style preference matches with the traditional Iranian English teaching methods. Moreover, there are several other studies that 
acknowledge female use auditory learning style for learning English (Melton 1990; Thomas et al., 2001; Tai 1999; Honigsfeld \& Dunn 2006).

Kinesthetic leaning was the most preferred learning style of the male students because of their willingness to do more activities and to be violent and courageous. The finding was consistent with the research result of (Melton 1990; Honigsfeld and Dunn 2003). Moreover, other studies have investigated gender and learning style. They found that male preferred kinesthetic learning style (Alsafi 2010; Mulalic, Shah, \& Ahmad 2009). From the female student's interview responses (examples: extract 1,2, and 3), female students declared that they were more auditory and also from the male student's interview responses (examples: extract 4, 5, and 6), male students stated that they were more kinesthetic.

\subsubsection{Female Students}

Extract 1

G1Q2L10 Auditory learning style is the perfect way in my English learning. (Line 43)

Extract 2

G1Q2L11 I prefer most auditory learning style. (Line 44)

Extract 3

G1Q2L15 I prefer to learn by listening. (Line 48)

\subsubsection{Male Students}

Extract 4

G2Q2L3I learn best by participate actively in activities. (Line 34)

Extract 5

G2Q2L10 I prefer kinesthetic learning style. (Line 41)

Extract 6

G2Q2L13 kinesthetic learning style is useful and helps me to learn better. (Line 44)

Most of the male students did not like to use tactile learning style. Male students use this learning style as their least preferred because of the traditional English teaching methods. The result about tactile learning style was consistent with Alsafi's (2010) findings. From the female students' interview responses (examples: extract 7, 8, and 9), the female students stated that their least preferred style is kinesthetic and also from the male students'interview responses (examples: extract 10,11, and 12), male students declared that their least preferred style is tactile learning style.

\subsubsection{Female Students}

Extract 7

G1Q4L4 I do not like to learn by participating in activities. (Line 93)

Extract 8

G1Q4L11 I do not prefer to learn English by kinesthetic learning style. (Line 100)

Extract 9

G1Q4L13 I do not like to learn by role-playing in the classroom. (Line 102)

\subsubsection{Male Students}

Extract 10

G2Q4L7I do not like to use writing and drawing for language learning. (Line 84)

\section{Extract 11}

G2Q4L8I do not prefer tactile learning style. (Line 85)

\section{Extract 12}

G2Q4L17 I do not like to have hand-on experiences with materials. (Line 94)

\subsection{The Reasons for Utilizing the Most Preferred and Least Preferred Learning Style of Female and Male Students}

Below are the responses given by the male and female students to research question 3 (the third and fifth question) in the interview. Section 4.3.1 and 4.3.2 explained the reasons for the most preferred learning style of female and male students.

\subsubsection{Auditory Learning Style (Female)}

Most of the female students from Marefat Iranian EFL high school preferred auditory style in learning English. The finding was consistent with Thomas et al., (2001) finding. From the female student's interview responses (extract 13, $14,15,16,17,18,19,20$, and 21). There were seven students who admitted that they preferred using more auditory style in acquiring English because with this method they can memorize and learn the English language better than the other methods. "Listening is important and they can improve their English" Two of those students said. 
The students' responses can be seen as follows:

\section{Extract 13}

G1Q3L1Because I think $90 \%$ of the learning occurs through this method that is better than the other kinds of learning styles. (Line 55-57)

\section{Extract 14}

G1Q3L4Listening skill is very important. I want to have more listening practice because I want to improve my English. (Line 61-62)

Extract 15

G1Q3L6This learning helps me to memorize the language better. (Line 64)

Extract 16

G1Q3L10 I can learn language better through this learning style. (Line 69)

Extract 17

G1Q3L11 when I listen too much, I can memorize and learn English language easily and with repetition it will stand more in my mind. (Line 70-71)

Extract 18

G1Q3L12 we have many opportunities to practice listening in our classes. Our teachers usually use English language to teach English and they don't use Persian. I can learn the English language better with this method. (Line 72-75)

\section{Extract 19}

G1Q3L14 Listening is important skill in learning English as a Foreign language for this reason I try to improve my listening. (Line 77-78)

\section{Extract 20}

G1Q3L15 Because when I listen to English language, I can learn and memorize the language better. (Line 7980)

\section{Extract 21}

G1Q3L17 Because when I listen to my teacher or any person, I can learn better.

(Line 82-83)

\subsubsection{Kinesthetic Learning Style (Male)}

Most of the male students preferred kinesthetic style in learning English. This result was consistent with Mulalic, Shah, and Ahmad (2009) result. There were four students who stated that they were more kinesthetic because they liked to be active in class. Three of them said they are able to learn more and becomes better with the language. The other two students had different reasons. They mentioned the kinesthetic style can help them in having more concentration and motivation for learning. From the male students' interview responses (extract 22, 23, 24, 25, 26, 27, 28, 29, and 30). The students' responses can be seen as follows:

\section{Extract 22}

G2Q3L2Role-play activities help me to learn the language better. (Line 54)

Extract 23

G2Q3L3I can learn better by active participation in activities. (Line 55)

\section{Extract 24}

G2Q3L6With this method I can keep the language better in my mind (Line 58)

\section{Extract 25}

G2Q3L7with this style I am forced to respond to the activities, in class. When I am active, I can learn language very well. (Line 59-61)

Extract 26

G2Q3L10 Because it is motivating and leads me to learn more. (Line 65)

$\underline{\text { Extract } 27}$

G2Q3L13 Because I can learn better. (Line 68)

\section{Extract 28}

G2Q3L16 Participating in various activities, I can learn English better. That's why I think it's most useful way of learning English. (Line 71-7) 
G2Q3L17 I can have more concentration on English learning. (Line 73)

Extract 30

G2Q3L18

Because with this style, I can learn better. (Line 74)

Section 4.2.3 and 4.2.4 explained the reasons of least preferred learning style of female and male students.

4.2.3 Kinesthetic Learning Style (Female)

Most of the female students did not prefer kinesthetic learning style. The result was consistent with the finding of a previous study (Melton 1990). Four of them asserted that they were least kinesthetic because they do not like to be active or move around in the class. "This method is not useful" two of them explained. One of these students had a different opinion, she claimed it is not possible to learn and understand English with this style. From the female student's interview responses (extract 31, 32, 33, 34, 35, 36, and 37).

The students declared that they were least kinesthetic and their responses can be seen as follows:

\section{Extract 31}

G1Q5L2This learning style is not useful for me because I forget subjects with this method immediately. (Line 112-113)

Extract 32

G1Q5L4I do not like kinesthetic learning style because I feel uncomfortable to move around in the class. (Line 116117)

Extract 33

G1Q5L11 Because I cannot see the reason for moving around in the classroom. (Line 124)

Extract 34

G1Q3L13 Because I cannot learn or understand in this way. (Line 126)

Extract 35

G1Q5L14 I cannot use this style for learning English. It is not useful in my learning. (Line 127-128)

$\underline{\text { Extract } 36}$

G1Q5L16

I do not like to be active in English class. (Line 130)

Extract 37

G1Q5L17 I do not like to move around in the classroom. (Line 131)

\subsubsection{Tactile Learning Style (Male)}

Most of the male students did not like to use tactile learning style. The finding was consistent with Alsafi's (2010) finding. These seven students stated they least preferred least tactile learning style because they could not learn with this method. Not being necessary, not useful and having no effects on learning were the reasons to support their views. From the male students' interview responses (extract 38, 39, 40, 41, 42, 43, and 44). The students' reasons are as follows:

Extract 38

G2Q5L7 I cannot learn with this method. (Line 107)

Extract 39

G2Q5L8 This method has a little effect on my learning. (Line 108)

Extract 40

G2Q5L9 Because I cannot study English with this style. (Line 109)

$\underline{\text { Extract } 41}$

G2Q5L10 I think this style is not necessary for learning English. (Line 110)

Extract 42

G2Q5L16 Because I think it's not useful for learning. (Line 118)

$\underline{\text { Extract } 43}$

G2Q5L17 I cannot learn in this way. (Line 119)

Extract 44

G2Q5L20 It does not have any effect in my learning. (Line 122)

\section{Conclusion and Pedagogical Implications}

This study concluded that the learning style preferences of Iranian students were different according to their gender. Most of the female students preferred auditory learning style, while the favorite or most preferred learning style of the most male students were kinesthetic. The least preferred learning style of the female students was kinesthetic, whereas the male students chose tactile learning style as their least preferred. This has a significant impact on pedagogy where 
the teachers must understand why some students have particular learning style preferences and these preferences may be different between the male and female students. Therefore, gender difference should be taken into account when teaching foreign languages.

This study yields information on the differences between the learning style preferences of male and female students which is positive for classroom applications. The results of this study can be used in other studies on learning styles for growing body of literature. Particularly, the findings improve our understanding of learning style preferences of the EFL high school students. "Inventories of learning style can be used to help make students aware of their own preferences and strengths" (Claxton and Murrell 1987: vi). Furthermore, knowing how learning process can be achieved by different styles is important in developing and improving learning of students (Vaseghi et al. 2012). It is generally recognized that classroom activities and instruction methods should be given by teachers that challenge their students. Consequently, understanding their students' learning style preferences and knowing the differences between gender learning style preferences could be useful for teachers. This study would not only help improve the learning process among students but also help to improve teachers' teaching style in EFL English language classrooms.

\section{References}

Ahmad,A. (2011). Language learning style preferences of Low English proficiency(LEP) students in a tertiary institution. Malaysian Journal of ELT Research 7 (2): 33-62.

Alsafi, A. (2010). Learning style preferences of Saudi Medical students. Master thesis. Essex University. (online) http://www.essex.ac.uk/linguistics/dissertations/2010/docs/Alsafi.pdf (19 August 2011).

Arbaugh, J. B. (2000). 'An exploratory study of the effects of gender on student learning and class participation in an Internet-based MBA course'. Management Learning 31 (4): 503-519.

Bidabadi, F. \& Yamat, H. (2010). Learning style preferences by Iranian EFL Freshman University students. Master thesis. Bangi: University Kebangsaan Malaysia. (online)

http://www.sciencedirect.com/science/article/pii/S1877042810020355 (26 April 2011).

Borich,G.D. \&Tombari, M.L. (1997). Educational Psychology: a contemporary approach. London: Addison-Wesley Educational Publisher Inc.

Brown,H.D. (2000).Principles of language learning and teaching. NY: Pearson Education.

Claxton, C.S. \& Murrell, P.H. (1987). Learning styles: implications for improving Educational practices AAHE-ERIC/ Higher Education Report, No. 4 Washington, D.C: Association for the study of higher Education.

Crookes, G. \& Schmidt R. W. (1991).Motivation: reopening the research agenda. Language Learning, 41(4): 469-512.

Crystal, D. (2003). English as a Global language, Second Edition, Cambridge University Press.

Dörnyei, Z. (1998). Motivation in second and foreign language learning. Language Teaching 31: 117-35.

Dörnyei, Z. (2005). The psychology of the language learner: individual differences in second language acquisition. London: Lawrence Erlbaum Associates, Publishers.

Dorsey, O. L., \& Pierson, M.J. (1984). A descriptive study of adult learning styles in a non-traditional education program. Lifelong Learning: An Omnibus of Practice and Research, 7, 8-11.

Dunn, R. (1988). Teaching students through their perceptual strength or preferences. Journal of Reading 31:304-309.

Dunn, R. (1999). How to implement and supervise a learning style program (On-line) http://www.ascd.org/publications/books/1996dunn/1996dunntoc.html (13 July 2011)

Dunn, R., \& Dunn, K. (1992). Teaching secondary students through their individual learning styles. Boston: Allyn \& Bacon.

Dunn, R., Griggs, S., Olsen, J., Beasley, M., \& Gorman, B. (1995). A meta-analytic validation of the Dunn and Dunn model of learning style preferences. The Journal of Educational Research 88(6):353-361.

Dunn, R. \& Griggs, S.A. (1998). Multiculturalism and Learning Style: Teaching and Counseling Adolescents. The USA: Greenwood Publishing Group, Inc.

Dunn. R., Thies, A. P., \& Honigsfeld, A. (2001). Synthesis of the Dunn and Dunn learning-style model research: Analysis from a neuropsychological perspective. Jamaica, NY: St. John's University. Center for the Study of Learning and Teaching Styles.

Ehrman, M. E., Leaver, B. L., \& Oxford, R. L. (2003). A brief overview of individual differences in second language learning. System 31: 313-330.

Feingold, A. (1992). Sex differences in variability in intellectual abilities: A new look at an old controversy. Review of Educational Research, 62, 61-84.

Felder, R. \& Brent, R. (2005). Understanding student differences. Journal of Engineering Education 94(1): 57-72

Felder, R. \& Henriques, E. R. (1995). Learning and teaching styles in foreign and second language education. Foreign Language Annals 28(1): 21-31. 
Gardner, R.C. (1985). Social Psychology and Second language learning: The Role of attitude and motivation. (London: Edward Arnold).

Hajbaghery, M. \& Aghajani, M. (2011). Traditional lectures, Socratic Method and Student Lectures: Which One do the students prefer? Webmed Central Medical Education 2(3):WMC001746.

Harasyrm, P. H., Leong, E. J., Lucier, G. E., \& Lorsheider, F. L. (1995). Gregoric learning styles and achievement in anatomy and physiology. Advances in Physiology Education 13(1):s56-s61.

Hudson, G. (2000). Essential introductory linguistics. Blackwell Publishers.

Hohn,R.L. (1995). Classroom learning and teaching. The USA: Longman Publisher.

Honigsfeld, A. M. (2001). A comparative analysis of the learning styles of adolescents from diverse nations by age, gender, academic achievement level and nationality. Ph.D dissertation, Dissert Abstr Int, 62, 969.

Honigsfeld, A.M. \& Dunn, R. (2003). High school male and female learning-style similarities and differences in diverse nations. The Journal of Educational Research 96 (4): 195-204.

Honigsfeld, A.M. \& Dunn, R. (2006). Learning-style characteristics of adult learners. Delta Kappa Gamma Bulletin, (Winter) 72(2): 14-31.

Isemonger, I. \& Sheppard, C. (2003). Learning Styles. RELC Journal 34 (2): 195-222.

Kalsbeek, D. H. (1989). Linking learning style theory with retention research. Association for Institutional Research 32: $1-7$.

Kang, S. (1999). Learning styles: implications for ESL/EFL instruction. Forum 37(4): 1-6. (ERIC Document Reproduction Service EJ 601615)

Keefe, J. W. (1979). Student learning styles: Diagnosing and prescribing programs. (p 4) Reston, VA: National Association of Secondary School Principals.

Lay Cock, V. K. (1978). Assessing learning characteristics. In Robert M. Anderson et al. (Eds). Individualizing materials for special children in the main stream" Baltimore University, Park Press.

Long, M. (1991). An Introduction to Second Language Acquisition Research. London: Longman.

Melton, C.D. (1990). Bridging the cultural gap: a study of Chinese students' learning style preferences. RELC Journal 21 (1): 29-54.

Mulalic, A., Shah, P., \& Ahmad, F. (2009a). Learning- style preference of ESL students. Asean Journal of Teaching and Learning in Higher Education 1(2):9-17.

Young, D. J. (Ed.) (1999). Affect in foreign language and second language learning: A practical guide to creating a lowanxiety classroom atmosphere. Boston: McGraw-Hill College. pp. 216-237.

Oxford, R.L. (2003). Language learning styles and strategies: An overview. Learning Styles \& Strategies/Oxford,GALA.

Oxford, R. L., Ehrman, M. E., \& Lavine, R. Z. (1991). "Style wars": Teacher student style conflicts in the language classroom. In S. Magnan (Ed.), Challenges in the 1990s for college foreign language programs . Boston, MA: Heinle \& Heinle. pp. 1- 25.

Pettigrew, F. \& Zakrajesk, D. (1984). A profile of learning style preferences among physical education majors. Physical Educator 41(2): 85-89.

Printrich, P. R.\& Schunk, D. H. (2002). Motivation in education: theory, research, and application. $\left(2^{\text {nd }}\right.$ Ed.). New Jersey: Merrill Prentice Hall.

Rashidi, N. (1995). Teaching and learning English in Guidance and high schools in Kordestan: Problems and suggested solutions, Online master Thesis, University of Shiraz, Iran.

Reid, J. M. (1987). The learning style preferences of ESL students. TESOL Quarterly 21(1):87-111.

Reid, J.M. (ed.) (1995). Learning styles in the ESL/EFL classroom. Boston: Heinle and Heinle.

Reinert, H. (1970). The Edmonds learning style identification exercise. Edmonds, EA:Edmonds School District.

Riazi, M. \& Riasati, M. J. (2007). Language learning style preferences: a case study of Shiraz EFL Institutes. The Asian EFL Journal Quarterly 9 (1):97-125. (Online) http://www.asian-efl-journal.com/March_2007_EBook.pdf (10 June2011)

Riazi, A. \& Mansoorian, M. A. (2008). Learning style preferences among Iranian male and female EFL students. The Iranian EFL Journal Quarterly 2: 88-100. (online) http://www.iranian-efl-journal.com/Iranian-EFL-Journal-secondedition.pdf (20 June 2011).

Rosniah Mustaffa. (2007). "Stretching” ESL Learners Learning Styles: a case studuy of first year undergraduates at UKM.GEMA Online Journal of Language Studies.Vol.7(1).(online)

http://www.ukm.my/ppbl/GEMA\%20vol\%207\%20(1)\%202007/abs\%20p1_32_v7(1).pdf(15 September 2011).

Sims, R. R. \& Sims, S. J. (1995). Learning enhancement in higher education. In R. R. Sims \& S. J. Sims (Eds.), The importance of learning styles. Westport, CN: Greenwood Press. pp.89-98. 
Skinner, B. F. (1974). About behaviorism. New York: Knopf.

Tai, F.M. (1999). Preferred teaching styles of Taiwanese EFL teachers and preferred learning styles of traditional and nontraditional EFL students(Doctoral dissertation, University of South Dakota).(online) http://ir.lib.ksu.edu.tw/bitstream/987654321/3032/1/\%25E8\%25AB\%2596\%25E6\%2596\%2587.pdf (11 may 2011)

Thomas Young Tachie. (2010). Learning style preferences as predictor of performance in science in public junior secondary schools in Ghana. Thesis Master, University of Education, Winneba, Ghana.

Vaseghi, R., Barjesteh, H., \& Shakib, S. (2013). Learning Style Preferences of Iranian EFL High School Students. International Journal of Applied Linguistics and English Literature, 2(4), 83-89.

Vaseghi, R., Ramezani, A.E., \& Gholami, R. (2012). Language Learning Style Preferences: A Theoretical and Empirical Study. Advances in Asian Social Science.

Wang Chu, M. (1992). Chinese students learning a foreign language survey. "China English Learning Psychology”,Gui Shichun ed. Hunan: Hunan Education Press. pp.72-89

Willing, K. (1988). Learning styles in Adult Migrant education. Adelaide, Australia: NCRC/AMEP.

Willis,D. (2001). Second language acquisition. Birmingham: University of Birmingham.

Wong,W. H. (2010). Mainland Chinese students' English language learning style preferences at a community college in Hong Kong. Bachelore thesis, university of Hong Kong.

Yong, F.L. \& McIntyre, J.D. (1992). A comparative study of the learning styles preferences of students with learning disabilities and students who are gifted. Journal of Learning Disabilities 25(2): 124-132. (Online) http://ldx.sagepub.com/content/25/2/124.short (1 October 2011).

Young Tachie, T. (2001). Learning style preferences as predictor of performance in Science in Public Junior Secondary schools in Ghana. Department of Science Education. University of Education, Winneba.

\section{APPENDIX A}

\section{INTERVIEW QUESTIONS}

\section{Structured Interview Questions}

$$
\begin{array}{cr}
\text { Female: } & \text { Male } \\
\text { خآقا } &
\end{array}
$$

\section{Questions}

1. To what extent are you familiar with these perceptual learning styles: visual, auditory, kinesthetic, tactile, individual and group learning? تا جه اندازه با اين روشهائى يادكيرى آشنايى داريد: يادكيرى از طريق ديدن ،شنيدن،فعاليت كلاسى، لمس

2. Which learning style do you prefer, mostly?

3. Why do you prefer this learning style mostly?

$$
\text { كدام روش يادكيرى را بيشتر نرجيح مى دهيد؟ }
$$

4. Which learning style do you prefer least?

$$
\text { جر ا اين روش را بيشتر ترجيح مى دهيد؟ }
$$

5. Why do you prefer this learning style least?

$$
\text { جر ا اين روش را كمنر ترجيح مى دهيد؟ }
$$

